\title{
Analysis and Reference of Renewable Energy Development in Developed Countries
}

\author{
Meng Jie \\ International Information Research Department \\ Beijing Institute of Science and Technology \\ Beijing, China \\ mengj@bjstinfo.com.cn
}

\author{
An Ran \\ General Office \\ Beijing Institute of Science and Technology \\ Beijing, China \\ anr@bjstinfo.com.cn
}

\begin{abstract}
The development and utilization of renewable energy sources and increasing the proportion of renewable energy in energy production and consumption structure is one of the ways to reduce greenhouse gas emissions. At present, the development of renewable energy in the world is widely concerned by many countries, and it has been a topical in international energy field. Since 2016, in order to promote renewable energy technology development, the developed countries have taken measures to establish new scientific research institutions and policies. The developed countries expect to combine with science and technology development advantages to promote renewable energy development of the country. The article collects developed countries in the field of renewable energy related research reports, policy initiatives and analysis research. By applying comparative method to analyze and research, the government promotes renewable energy technology development in china. The authors propose some suggestions from aspects of government policy formulation, organization structural establishment and industrial structure adjustment.
\end{abstract}

Keywords--Climate change; Renewable energy; Science and technology policy;Industrial restructuring

\section{INTRODUCTION}

The development and utilization of renewable energy sources and increasing the proportion of renewable energy in energy production and consumption structure is one of the ways to reduce greenhouse gas emissions. At present, the development of renewable energy in the world is widely concerned by many countries, and it has been a topical in international energy field. Photovoltaic power generation, wind power and other new energy annual growth rate in $20 \%$ higher per year. Renewable energy has become a significant alternative energy sources to achieve energy diversification, climate change and society sustainable development [1].

\section{CHINA'S RENEWABLE ENERGY DEVELOPMENT AND ISSUES}

The purpose of the development and utilization of renewable energy in China is mainly to solve rural energy shortage problem. Back in the 70s, the Chinese government has issued a series of policies to support renewable energy construction in rural areas. With introduction of these policies and measures, China's renewable energy development and utilization is in a leading position in developing countries, such as small hydropower, solar thermal utilization and rural biogas technology.In the late 80s, China also started in the research and development of modern technology, renewable energy utilization, especially in solar power, wind power and biomass liquid fuel spending increased significantly, and has a certain development.China's modern renewable energy technology research, development and utilization has started, especially in solar electrical energy generation, wind power generation and bio liquid fuel investment has be markedly increased in investment, and has a certain development [2].

Currently, the overall level of China's preferential policies for promoting renewable energy development is not much difference compared with foreign countries, but there are still some problems to be solved: firstly, Operational measures need to be strengthened. To financial subsidies, for example, the developed countries for renewable energy investment projects with large subsidies, generally more than $40 \%$.To financial subsidies, for example, developed countries have large subsidies for renewable energy investment projects, generally more than $40 \%$. China's renewable energy investment projects have a narrow range of subsidies.Secondly, it is relatively weak for China using tax measures to support renewable energy development. The practical level of most renewable energy projects is closed to and conventional source of energy taxes,it cannot reflect on renewable energy development preferential treatment. Finally, the policy of promoting the development of renewable energy in our country still has the problem of poor continuity.Some policies in the implementation process, due to original agency or competent authority cancellation, or the lack of funds for the development of special funds, so that the whole policy implementation had no choice to be interrupt.

In addition, institutional and capacity building is one of factors for restricting the of renewable energy development in china [3]. In most developed countries, there is a National Renewable Energy Research Institute, which is engaged in research on renewable energy policy, technology development route and key technologies. However, most of relevant policy formulation and research and development in China are scattered in hundreds of departments and universities. It is not unable to form a combat team. 


\section{RENEWABLE ENERGY DEVELOPMENT IN DEVELOPED}

\section{COUNTRIES}

\section{A. Germany continues to implement "EXIST"}

\section{entrepreneurship promotion policy}

Germany has been kept a positive attitude on renewable energy issues, and has constantly introduced and refined various stimulus measures. In March 2, 2016, the German Federal Ministry for Economic Cooperation and Development announced the launch a new round of "EXIST" entrepreneurship within the funding policy framework. The proposed funding scheme is currently extended to "EXIST-Gruenderstipendium (initial scholarship) "and "EXIST-Forschungstransfer (research transfer)".Since December 9, 2014 the government has increased funding efforts, which has funded for high tech research intensive and high risk transformation of scientific research achievements from $€ 70,000$ to $€ 250,000$. The government has priority supported clean technology, energy and life sciences fields, and further improved relevant funding conditions to better fulfill energy and clean technology needs.

In 1997, Germany had begun to support implementation of University Entrepreneurship "EXIST" Policy, initiated sponsored by the Federal Ministry of Education Research, and later handed over manage by the Federal Ministry of Economics and Technology. This policyhad brought into high-tech strategic framework, which aimed to improve the environment for scientific research institutions establishment, and accelerate the start-up technology and knowledgeintensive enterprises.The "EXIST" policy objectives are: improving entrepreneurial environment of German universities and colleges, cultivating enterprise culture in universities, and increasing enterprises establishment in the University.The core of "EXIST" entrepreneurship promotion policy is to support entrepreneurship early concept [4].

German Federal Ministry of Economic Affairs and Energy (BMWi) launched a new round of funding programs, and to participate in the competition of 11 universities to provide initial funding of $\$ 8$ million.Federal Department of Energy launched a new round of funding programs, and participated in 11 comprehensive university competitions to provide initial funding of $€ 8$ million.In this regard, the Minister of Federal Economic Energy Department, Sigma Gabriel, pointed out that economic development of developed countries cannot be separated from the high level of scientific imagination. The necessary condition to determine the competitiveness of enterprises is the rapid conversion of scientific research into products and services. The introduction of new ideas under university environment is an important factor in the start-up of innovative enterprises.The implementation in funding programs will enhance an undertaking enthusiasm of students and research specialist staff, the government will continue to take advantage of policies and funding to support innovative enterprises development.Hereafter, we will continuously to improve funding conditions for "EXIST" entrepreneurship promotion policies, increase support, and achieve the goal of setting up 220 innovative enterprises with development potential every year.

\section{B. Finland adoption of new energy investment act}

Finland, as one of the most developed countries in the world, with the most perfect welfare and the most environmentally protection, has some problems such as lack of energy resources and long-term dependence on imports. To solve the above problems, further reduce greenhouse gas emissions, and protect domestic environment, the Finland government has been committed to improving energy efficiency and utilizing renewable energy development.

February 25, 2016, the Finland Government approved "Government Decree on General Terms of Granting Investment Aid for Renewable Energy and New Energy Technology". The formulation of this law is mainly in order to promote the implementation of scientific and technological research and development activities in biotechnology and green technology, to solve future energy issues, and to achieve the goal of reducing carbon emissions in Finland.

To support this sustainable development, the Government planned to increase renewable energy large proportion, the goal is raised to more than $55 \%$ of country's overall energy consumption during the 2020s. It is planned to increase the proportion of renewable energy using proportion in transportation field whichrenewable energy use will rise up more than $40 \%$. Finland will suspend the use of coal, and oil imports will be reduced by more than $50 \%$ in 2020. The government planned to invest EUR 80 million in research funding between 2017 and 2018, primarily for production biofuels transportation.In addition, the government planned to invest in new energy projects by EUR 5 million [5]. The government will determine the allocation of funds for scientific research on comprehensive basis research of scientific research projects. The main investigated factors are energy production, investment funding utilization effect, technical practicability, etc.

\section{United States Department of Energy set up technology transfer office}

The U.S. Department of Energy has been playing an important role in renewable energy planning. In February 11, 2015, the U.S. Department of Energy has created a new Office of Technology Transitions (OTT) to help expand the commercial impact of its research projects, and in order to enhance the commercialization of research findings of the Department of Energy. OTT will work closely with the national laboratories and industries to achieve related technologies commercialization and enhance global competitiveness of the U.S. energy industries based on technological innovation.

OTT as a functional institution of the Department of Energy will coordinate all sectors (including 17 national laboratories and other research and production facilities) commercial development and utilization of research findings, and is responsible for the Technology Commercialization Fund (TCF). The fund was established in accordance with "the US Energy Policy Act of 2005", a total of nearly \$20 million, which is accounting for $0.9 \%$ of the Department of Energy each fiscal year budget in applied energy research, 
development, demonstration and commercialization fields. The foundation will be through applied energy projects in research and development funds, to launch highly influential commercial activities [6]. These investments will work with private partners to jointly promote potential energy technology to achieve commercial application.

Department of Energy's annual R \& D investment is total about more than $\$ 10$ billion, $\mathrm{R} \& \mathrm{D}$ activities carried out mainly by universities and federal laboratories. These investments are primarily support for innovative basic research by driving low carbon economy environment and protecting U.S. nuclear security innovation Based research basic research on the transition to a low carbon economy and the protection of U.S. nuclear security. By OTT's function, the Department of Energy will promote technologies transfer to market, and realize organic connection in different stages of demonstration.

OTT is also responsible for submitting technology transfer plan to Congress annually and reporting technology transfer and partner activities of the Department of Energy. The Director of OTT as a legal technology transfer coordinator provides technical and commercial activities suggestions.

\section{CHINA'S RENEWABLE ENERGY DEVELOPMENT REFERENCES}

In the energy sector setting, developed countries have set up a corresponding national renewable energy agency; they provide technical guidance and research funding for the relevant institutions and enterprises which engaged in renewable energy, from the national level unified organization and coordination of renewable energy technology research and development and industrialization, and unified organization and coordination in renewable energy technology industrialization from national level [7].

In terms of government support, governments have adopted a positive attitude towards renewable energy issues, and invested heavily in renewable energy research and development to guarantee policy implementation smoothly.

In terms of laws and regulations, according to actual situation of each country, the governments issued corresponding laws and regulations. Through a series of preferential policies and supporting measures development, As well as coordination ability of market economy, the governments encourage renewable energy investment and utilization, and constantly improve in practice, to adjust actual value of renewable energy technology to the maximum extent.

Based on dynamic analysis of renewable energy scientific and technological development in developed countries, the author puts forward following suggestions for China's renewable energy development.

\section{A. Increasing $R \& D$ investment}

Foreign developed countries have made great achievements in renewable energy field from initial emphasis on $\mathrm{R} \& \mathrm{D}$ emphasis of key technologies.Therefore, when developing renewable energy in China, not only pay attention to attach importance to renewable energy research and development, to form a sustainable incentive system combining production, learning and research, but also invest core technology research,advanced equipment and technical aspects in core-competitiveness. China's biomass power generation, biomass liquid fuels, biomass solid fuel manufacturing technology is relatively mature. However, the development of China's biomass energy has not formed an integrated system. Biomass energy utilization should be higher in the European countries to learn to form biomass energy utilization system.

\section{B. Increasing tax incentives}

Most countries provide strong incentives for renewable energy development, including a high financial subsidies and tax incentives. In contrast, China's preferential policies for renewable energy is less, should continue to intensify efforts to provide preferential policies to conducive development of tax incentives tax preferences and financial incentives, to create a good environment for renewable energy development. Meanwhile, we can follow German's phased compensation policy to encourage enterprises to enter the market operation.

\section{Implementing flexible financing policy}

The establishment of new energy and renewable energy industry investment foundation is a necessary condition, which can increase capital market financing, encourage foreign direct investment, and broaden equity trading financing channels. Through various financing methods, raise funds through multiple channels, promoting industrialization process.

\section{Organizing implementation demonstration projects}

Chinese government should promote construction of renewable energy demonstration projects, and guide enterprises to participate actively. Drive development and popularization in manufacturing technology and expand application. Through demonstration projects to improve localization of application equipment, reduce equipment required cost, in order to gradually accelerate renewable energy industrialization process.

\section{E. Taking appropriate localized manufacturing incentive measures}

In the new energy and renewable energy in the process of project construction, the government needs to gradually increase manufacturing equipment localization proportion. Based on introduction, digestion and absorption, and gradually establish and perfect new energy and renewable energy industry.

\section{F. Improving laws and regulations}

Renewable energy laws and regulations are important means to ensure the healthy development of renewable energy industry.The introduction of laws and regulations should be supplemented and improved its implementation details, including a clear beneficiary, implementation scope, and subsidies submitand preferential tax rates and other details; on the other hand, we should improve system relevant incentive measures, in order to regulate renewable energy industry development.

Specific implementation measures are: 
- Establish and improve the market access policy, market regulation and service policy; Strengthen information and personnel training policy;

- Encourage international cooperation and introduce international advanced technology and capital policy;

- Increase awareness of environmental awareness and education policy;

- Develop and improve renewable energy generation quota policy;

- New energy and renewable energy generation to maintain or occupy a certain proportion;

- In order to enable a variety of new energy and renewable energy to bid on the Internet.

\section{CONCLUSION}

With the increasingly serious environmental problems, exploitation and utilization of renewable energy is still a problem to be solved urgently in China. It is significant to promote sustainable development, improve people's living standards, and advance adjustment and upgrading of industrial structure in China.

\section{REFERENCES}

[1] "EXIST"Entrepreneurship Promotion Program [Z] German Federal Ministry of EconomicAffairs and Energy (BMWi) Website:http://www.bmwi.de

[2] "General Conditions for Renewable Energy and New Energy Technologies Determination" [Z] Ministry of Economic Affairs and Employment Website:http://www.tem.fi

[3] 《Possibility Report of Algae Biofuel Technology》[Z] European Commission Joint Research Centre Website : https://ec.europa.eu

[4] Stephany Griffith-Jones, Jose Antonio Ocampo, Stephen Spratt. Financing Renewable Energy in Developing Countries: Mechanisms and Responsibilities, European Report on Development, (2012).

[5] Xing ZHANG, Hong-Wei DING. Renewable Energy Resources Development in China. From the Aspects of Policies and Strategic Planning. Advances in Electrical Engineering Systems (AEES) 177 Vol. 1, No. 4(2012). 177-181. (In Chinese)

[6] Paolo Cozzi. Assessing Reverse Auctions as a Policy Tool for Renewable Energy Deployment. The Center for International Environment \& Resource Policy. (2012).

[7] Mario Ragwitz, Simone Steinhilber, Barbara Breitschopf. RE-Shaping: Shaping an Effective and Efficient European Renewable Energy Market. A Report Compiled within the European Research Project RE-Shaping. (2012). 